
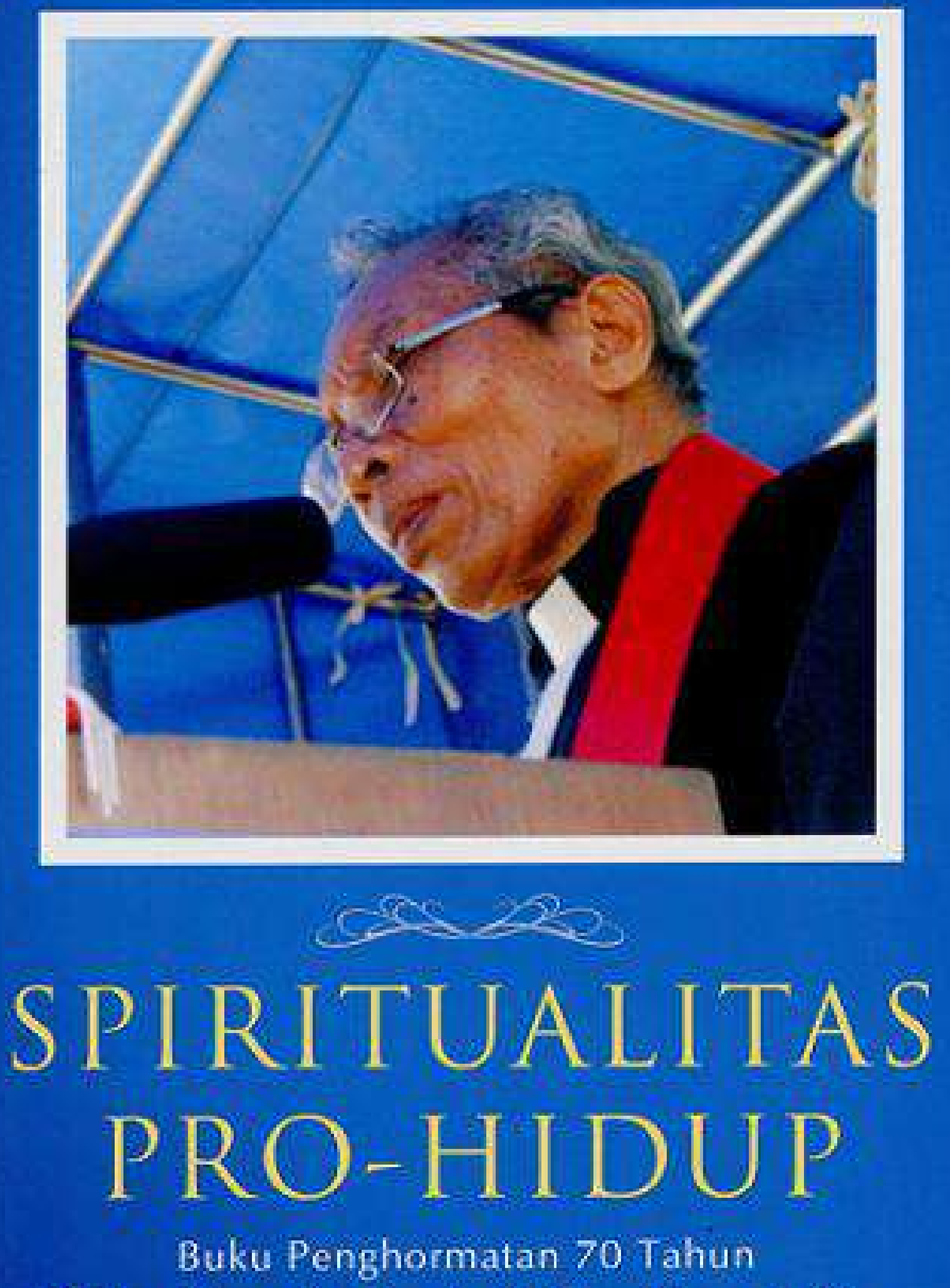

Pdt. (Em.) Dr. I.W.J. Hendriks

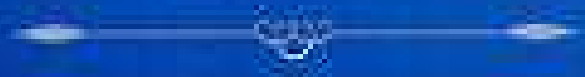

5 misumatin:

A Matio Ballifiery, Ri Simson,

1. Tuasela kelwutan. If Samina;

Q. Rahabeat, H. H. Hesharia 


\section{Daftar lsi}

Sambutan Dekan Fakultas Teologi UKIM

Catatan Penyunting

\section{BAGIAN PERTAMA: KITAB SUCI DAN TAFSIR KEHIDUPAN}

1. Siapakah Anak Allah Itu? (Suatu Kristologi Markus yang Kontekstual) oleh Dr. H. Talaway

2. Gereja Merawat Kehidupan oleh Uskup Mgr PC Mandagi, MSC

3. Narasi Perdamaian Yesus:Membaca Identitas Sosial dan Rekonsiliasi dalam Yohanes 4:1-26 oleh Izak Lattu, Ph.D.

4. Makan Bersama Sebagai Gambaran Keluarga Allah. "Kajian terhadap Injil Lukas dan Kontribusinya bagi Pemikiran Teologi-Eklesiologis“ oleh Dr. Nancy Patty

\section{BAGIAN KEDUA: GEREJA DAN KEPEMIMPINAN KRISTIANI}

1. Kepemimpinan Visioner oleh Dr. Albertus Patty

2. Kepemimpinan Kegembalaan Sebagai Model Kepemimpinan Gerejawi oleh Pdt. Elifas Maspaitella, M.Si

3. Kepemimpinan Hamba oleh Rachel Iwamony, Ph.D

4. Kepemimpinan dan Keuangan Gereja oleh Pdt. Max Chr. Syauta, S.Th.

1. The Case For God: Allah di Tengah-tengah Masyarakat Majemuk (Indonesia) oleh Dr. A. A. Yewangoe 
2. Merawat Pluralisme Bersama GPM oleh Dr. John Ruhulessin

3. Merajut Keragaman Etnisitas Dalam Gereja oleh Pdt. Rudy Rahabeat

4. GPI dan Kontribusinya Bagi GPM oleh Dr. M. Tapilatu

\section{BAGIAN KEEMPAT: GEREJA DAN KONTEKSTUALISASI}

1. Berteologi dengan Ketulusan Hati dan Budi oleh Prof. Dr. Aholiab Watloly

2. Menghidupkan Kembali Kaidah Emas (Golden Rule) sebagai Upaya Memperkuat Masyarakat Multikultural di Maluku (Suatu Tawaran Etika Agama-agama yang Pro-Hidup) oleh Pdt. Dr. Henky H. Hetharia, M.Th

3. Krisis Ekologi dan Panggilan Merawat Bumi dengan Semangat Spiritualitas Ekofeminis oleh Dr. Eklefina Pattinama, M. Hum

4. Partisipasi Trinitaris. Menggali Teologi Trinitaris Dari Sistem Tiga Batu Tungku Sebagai Acuan Berteologi oleh Pdt. Yery Takdare

\section{BAGIAN KELIMA: KENANGAN DARI PARA SAHABAT, KOLEGA DAN KELUARGA}

1. Kenangan Bersama Pdt. (Em.) Dr. IWJ Hendriks oleh H. Drs. Idrus Toekan

2. Orang Yang Hebat Itu Sederhana oleh Dra. B. Pattiselano, M.Pd

3. Kenangan Para Nitizen

4. Berbagi Hidup Bersama Suamiku oleh Pdt. Dr. MM. Hendriks-Ririmasse

\section{Lampiran}

1. Biodata

2. Dalam kenangan (foto) 


\section{SPIRITUALITAS PRO-HIDUP}

\section{Buku Penghormatan 70 Tahun Pdt. (Em.) Dr. I.W.J. Hendriks}

Copyright @ 2017

\section{Diterbitkan oleh}

Fakultas Teologi UKIM bekerja sama PT BPK Gunung Mulia

Jl. Kwitang 22-23, Jakarta 10420

E-mail: inspirasi@bpkgm.com

Website: http://www.bpkgunungmulia.com

Anggota IKAPI

Hak Cipta dilindungi oleh Undang-undang

Cetakan ke-1: 2017

Editor: Rika Uli Napitupulu-Simarangkir, Lautan Asima Siregar Korektor Naskah: Santoso S. B.

Tata Letak: Mikhael Buhis

Desain Sampul: Hendry Kusumawijaya

\section{Katalog dalam terbitan (KDT)}

\section{Batlajery, A.M.L. dkk.}

Spritualitas pro-hidup : buku penghormatan 70 tahun Pdt. (Em.) Dr. I.W.J. Hendriks / disunting oleh A.M.L. Batlajery, Roland Samson, Juliana Tuasela-Kelwulan, Johan Saimima, Rudy Rahabeat, H.H. Hetharia ; - Cet. 1. - Jakarta : BPK Gunung Mulia 2017. xiv, $287 \mathrm{hlm}$; $; 23 \mathrm{~cm}$.

1. Pelayanan-Gereja - Kekristenan.

I. Batlajery, A.M.L. II. Samson, Roland. III. Tuasela-Kelwulan, Juliana. IV. Saimima, Johan.

V. Rahabeat, Rudy. VI. Hetharia, H.H. VII. Judul.

\section{1}




\title{
Merawat Pluralisme Bersama Gereja Protestan Maluku (GPM)
}

\author{
Pdt. Dr. John Ruhulessin
}

Dosen Sosiologi Agama Fakultas Teologi

UKIM Ambon. Mantan Ketua MPH Sinode GPM

\section{Pengantar}

7 ulisan ini hendak menegaskan sebuah harapan, sekaligus komitmen untuk menjaga dan merawat pluralisme sebagai realitas sosial,

1 sekaligus teologis dalam hidup bergereja, bermasyarakat, berbangsa, dan bernegara. Hendak ditegaskan pula bahwa dalam gelombang sejarahnya, Gereja Protestan Maluku (GPM) terpanggil untuk menerima dan mengelola pluralisme agama, suku, adat, budaya, dan ideologi sebagai anugerah Tuhan. Dengan bersikap demikian, GPM bersama stakeholders lainnya turut menyumbang bagi sebuah peradaban yang humanis dan beradab.

Gereja Protestan Maluku (GPM) merupakan salah satu gereja tua dan besardi kepulauan Maluku. Fakta ini seringkali tak diperhatikan secara baik atau malah salah dimengerti. "Makin tua makin berisi", mestinya demikian dengan GPM. Akan tetapi, bagaimana jika yang terjadi sebaliknya? Terjadi kemandegan atau kemacetan atau bahkan kemunduran dalam bergereja. Sebagai lembaga yang bertumpu pada pengharapan kepada Yesus Kristus Sang Kepala Gereja, maka kita yakin bahwa gereja akan tetap hidup seturut kehendak Pemiliknya. Namun, sebagai lembaga sosial keagamaan, maka 
diperlukan kepekaan dan komitmen yang kuat untuk terus merawat kehidupan bergereja yang sehat, dinamis, dan fungsional. Fokus tulisan ini adalah bagaimana GPM bersama gereja-gereja yang lain, agama-agama yang lain, pemerintah dan seluruh elemen masyarakat, dan bangsa bersama-sama merawat pluralisme. Fokus ini juga merupakan salah satu concern Pdt. Dr. IWJ Hendriks yang akrab disapa "Pa Brury", yang pernah menjabat Ketua BPH Sinode Gereja Protestan Maluku (GPM) periode 2000-2005. Tulisan ini adalah bentuk apresiasi dan terima kasih atas komitmen dan karya Pa Brury dalam merawat pluralisme itu.

\section{Fakta Pluralisme}

Konteks kehidupan sosial (di Indonesia dan Maluku) sejak awal merupakan suatu ruang publik yang plural. Corak pluralitas masyarakat tampak dalam berbagai segi kehidupan masyarakat dan yang selalu menjadi masalah pluralisme dalam bidang agama, etnis dan sub-etnis, juga faksi-faksi politik. Sebagai fakta masyarakat, pluralisme harus diakui dan diterima, bukan sebagai suatu sikap taktis, tetapi suatu kesadaran yang eksistensial. Penolakan dan pengingkaran terhadap fakta itu sama saja dengan penolakan atau pengingkaran terhadap eksistensi masyarakat atau eksistensi kemanusiaan.

Pluralisme masyarakat Indonesia adalah fakta objektif dari kenyataan Indonesia yang sesungguhnya, secara agama, kultural, etnis, pandangan hidup, bahasa, adat istiadat, dan lain-lain. Persoalannya adalah bagaimana diversitas (keragaman) masyarakat itu diwujudkan secara politis, kultural, ekonomi, dan sebagainya? Bagaimana kehidupan kolektif dan individu yang begitu bisa dibangun dalam kehidupan publik yang real? Bagaimana pula standar-standar moral yang disepakati, sehingga memungkinkan kehidupan bersama dapat dibangun dengan baik? Bagaimana pula suatu arah dan perspektif common-good dapat diletakkan, sehingga kehidupan bersama bisa berlangsung secara benar, baik, adil, dan setara tanpa dikriminasi?

Pertanyaan-pertanyaan di atas sengaja diajukan sebagai rangsangan, sekaligus agenda bagi gereja, khususnya Gereja Protestan Maluku, untuk mencari jawab dan memberi pertanggungjawaban atas mandat yang dipercayakan Tuhan kepadanya. Artinya, sejauh mana GPM peka dan tanggap dalam merespons pertanyaan-pertanyaan tersebut sebagai respons iman dan akta pelaksanaan amanat panggilannya di tengah-tengah dunia yang terus berubah ini. 
Fakta dan kepekaan tentang pluralisme dalam konteks kebangsaan juga ditegaskan oleh Persekutuan Gereja-Gereja di Indonesia. Salah satu dasar pemikiran Pokok Tugas Panggilan Bersama (PTPB) PGI 2014-2019 berbunyi:

Gereja-gereja di Indonesia menyadari bahwa ia adalah bagian yang tak terpisahkan dari seluruh bangsa Indonesia. Ia lahir dari tengah-tengah pergumulan masyarakat dan bangsa Indonesia sebagai buah pekerjaan Roh Kudus dan telah ditempatkan oleh Tuhan sendiri untuk melaksanakan panggilan-Nya dan menjadi sarana berkat bagi semua orang di Negara Pancasila yang sedang memulihkan diri dari berbagi krisis multidimensi, dijiwai oleh semangat reformasi yang dipelopori mahasiswa sejak tahun 1998. PTPB PGI 2014-2019.

Realitas yang sama juga, yakni pengakuan terhadap fakta pluralisme, menjadi pergumulan gereja-gereja se-dunia yang terhimpun dalam wadah Dewan Gereja-Gereja se-Dunia (WCC). Dengandemikian, hendak ditegaskan bahwa fakta dan respons terhadap pluralisme itu menjadi agenda lokal, nasional, dan global, agenda bersama agama-agama, bahkan agenda kemanusiaan.

\section{Posisi dan Peran GPM: Antara Problematika dan Apresiasi}

Merespons fakta pluralisme, khususnya pluralisme agama-agama, maka GPM sejak berdirinya 6 September 1935, berusaha merespons realitas tersebut antara lain baik melalui sidang-sidang gerejawi, maupun tulisantulisan teologis. Salah satu tulisan dimaksud adalah tulisan mantan Ketua Sinode GPM, Pdt. Dr. A.N. Radjawane yang berjudul Islam di Ambon dan Haruku (Sidjabat, 1964: 71-85). Dalam tulisan ini, Radjawane berusaha menggambarkan konteks agama-agama di Maluku, khususnya IslamKristen, dan bagaimana sikap Gereja (baca: GPM) dalam merespons realitas tersebut. Tulisan lainnya juga dapat dibaca pada buku Pdt. Dr. Pieter Tanamal (mantan Sekretaris Umum Sinode GPM) dalam bukunya Pengabdian dan Perjuangan (1987). Dalam buku itu Tanamal bahkan melakukan kritik substantif terhadap agama-agama samawi, yang menurutnya membawa "kekafiran baru", ketika terjadi konflik dan perang yang turut dipengaruhi agama-agama samawi itu.

Tragedi kemanusiaan yang paling perih yang turut menghadapkan agama-agama dalam posisi dilematis adalah peristiwa konflik Maluku 19 Janiuari 1999. Konflikyang mengakibatkan hilangnya ribuan nyawa manusia 
dan kerugian material yang luar biasa itu menjadi tantangan bagi agamaagama (termasuk GPM), untuk memberi respons yang tepat. Salah satu hikmah konflik itu adalah panggilan untuk membangun dialog dan kerjasama antar-agama yang lebih intens dan fundamental. Dalam PIP-RIPP GPM 2015-2025, hal itu ditegaskan dalam salah satu isu problematiknya. Saya mengutipnya agak panjang demikian:

Konflik Maluku dan seluruh dampaknya mempertegas bahwa dialog dan kerjasama lintas agama di Maluku merupakan salah satu isu sentral yang harus dikelola secara berkelanjutan. Segregasi berdasarkan agama tidak saja terjadi secara geografis, tetapi juga secara mental. Dalam wilayah yang tersegregasi, narasi-narasi kalah-menang terkait konflik masa lalu bertumbuh subur dan dialih-turunkan kepada generasi baru di Maluku. Trauma konflik belum seluruhnya tersembuhkan. Prasangka-prasangka dan pelabelan lintas kelompok berdasarkan perbedaan agama masih kental terasa. Tak dapat disangkal bahwa hubungan antar-pemeluk agama di Maluku memang terlihat semakin membaik dari waktu ke waktu, namun relasi yang terbentuk masih berpola toleransi pasif. Dalam kondisi itu, radikalisme agama berkembang menjadi salah satu fenomena yang mencemaskan kehidupan bersama di bangsa ini, dan turut mengimbasi kehidupan pemeluk agama di Maluku. Terhadap kenyataan ini, GPM telah melakukan berbagai upaya untuk membangun pengertian dan sikap saling menerima dengan pemeluk agama lainnya. Upaya ini perlu diteruskan dan ditingkatkan untuk mencapai level rasa saling percaya yang semakin tinggi antara para pemeluk agama di Maluku. Model tinggal bersama (live-in) antarpemeluk agamayang pernah dipelopori GPM (dan program lainnya) sepatutnya terus dikembangkan, sehingga penguatan relasi lintas agama tidak saja berlangsung di ruang publik, tetapi juga mengintervensi ruang-ruang domestik. Selain itu, kerjasama antar-para pemeluk agama mesti diarahkan untuk menangani persoalan-persoalan kemasyarakatan, ketidak-adilan sosial, degradasi lingkungan, serta penguatan tertib sosial dan pengawalan terhadap tata pemerintahan yang bermoral sebagai manifestasi dari relasi oikumene baru. PIP-RIPP GPM 2015-2025.

Kutipan diatas menunjukkan keseriusan GPM dalam menyikapi realitas pluralisme, khususnya pluralisme agama. Berbagai langkah dan program dilakukan oleh GPM, baik dalam aras jemaat, klasis, maupun sinodal untuk menumbuhkembangkan kesadaran dan praksis pluralisme yang saling menghidupkan. GPM mengkorporasikan kesadaran tersebut dalam institusi gereja, antara lain dengan adanya struktur baru yang bermuara pada oikumene semesta. 
Komitmen dan kiprah GPM dalam membangun kesadaran pluralisme itu kemudian hari mendapat apresiasi dari berbagai kalangan. Salah seorang intelektual Muslim Maluku, Dr. Abidin Wakanno memberikan apresiasinya dalam buku Gereja dan Kepemimpinan Publik, sebagai berikut:

Selama dua dekade terakhir, GPM telah mengembangkan iklim dialog dan perjumpaan agama-agama yang sangat progresif, khususnya pada masa kepemimpinan Bapak Pdt. Dr. IWJ Hendriks dan Bapak Pdt. Dr. John Ruhulessin. Kedua tokoh ini dapat diterima secara baik oleh umat beragama lain di Maluku, khususnya Muslim. Di masa kedua tokoh ini, dialog dan perjumpaan GPM dengan agama-agama lain, khususnya dengan Islam, berjalan sangat jujur, terbuka, dan intensif. Dari sini secara pribadi saya merasakan pengalaman spiritual yang sangat dalam, ketika berinteraksi dengan warga GPM. Kedua tokoh inilah yang membuka ruang sebesar-besarnya untuk para tokoh umat beragama lain, khususnya para tokoh Islam untuk masuk ke gereja dan naik mimbar gereja GPM" (Ruhulessin, 2015:32).

Apresiasi lainnya datang dari Prof. Sumanto Alqurtuby, yang saat ini merupakan staf pengajar di King Fahd University Arab Saudi, yang juga melakukan riset doktoral tentang relasi antar-agama di Maluku. Ia menulis apresiasinya dalam buku Merajut Cita Kemanusiaan Bersama: Pergulatan Keambonan dan Keindonesiaan.

Dalam konteks Ambon, saya melihat GPM sejak era Pdt. Hendriks dan puncaknya pada masa Pdt. John Ruhulessin telah melakukan terobosan yang luar biasa dalam melakukan berbagai upaya pembangunan perdamaian dan rekonsiliasi Kristen-Muslim Ambon. Prestasi ini tentu perlu dikembangbiakkan oleh GPM pascakepemimpinan Pdt. Ruhulessin ... GPM benar-benar mampu menjadi, seperti Pdt. Dr. John Ruhulessin sebutkan "dynamic engine" (mesin penggerak), yang tidak hanya menggerakkan mesin-mesin Kristen saja, tetapi juga mampu memengaruhi dan "menggarami" saudara seiman, sekaligus"adik bungsu" umat Islam. Sebagai "kakak", tentu saja umat Kristen memiliki tanggung jawab moral spiritual terhadap perkembangan sang "adik", agar tumbuh menjadi sosok yang penuh dengan wawasan terbuka, toleran, dan pluralis. Hanya dengan sikap, watak, dan spirit pluralisme inilah perdamaian sejati di Ambon bisa terwujud (Ruhulessin, 2016: xix-xx).

Kutipan-kutipan di atas tidak bermaksud menonjolkan peran dan kontribusi GPM dalam membangun dan merawat pluralisme di Maluku, tetapi hendak menegaskan bahwa apa yang dilakukan oleh GPM selama ini tidak percuma. Walau diperhadapkan dengan berbagai tantangan, GPM tetap konsisten dan berkomitmen dalam panggilannya untuk merespons 
realitas keragaman agama di Maluku. Kini pada kepemimpinan Pdt. AJS Werinussa, kesadaran dan komitmen GPM atas realitas pluralisme itu antara lain ditegaskan melalui wacana "Gereja Orang Basudara".

\section{Bersama GPM Merawat Pluralisme}

GPM tidak bisa seorang diri merawat pluralisme yang dimaknai sebagai anugerah Tuhan. Tantangan dan hambatan dalam merawat pluralisme pun tidak ringan. Berbagai tindakan radikalismeagama dan terorisme atas nama agama bisa menjadi alasan untuk "mundur" dari upaya merawat pluralisme itu. Namun, apa yang sudah merupakan "capaian" GPM dalam merespons fakta pluralisme itu harus dijaga dan ditingkatkan ke depan. Para pelayan, khususnya pendeta, penatua, dan diaken, harus menjadi agen-agen pluralisme, baik dalam kata maupun perbuatan. Demikian pula warga gereja yang juga merupakàn warga masyarakat dapat terus menjalankan fungsi dan tanggung jawab merawat kebersamaan dalam perbedaan. Berbagai pranata adat dan budaya, seperti Pela dan Gandong di Maluku Tengah, Ain ni Ain dan Larwul Ngabal di Kei, dan berbagai pranata yang telah teruji dapat mengelola pluralisme, perlu terus direvitalisasi. Tujuannya, agar keragaman (pluralisme) dilihat dan dimaknai secara positif dan fungsional, bukan sebaliknya.

Saat menulis tesis di program Magister Agama dan Masyarakat UKSW tahun 1993, rekomendasi yang saya kemukakan kepada GPM rasanya masih relevan. Berikut saya kutipkan rekomendasi itu:

Bagi GPM, penting untuk membangun suasana dialogis; keterbukaan dihidupkan melalui kegiatan-kegiatan yang bersifat akademik dengan wawasan-wawasan keagamaan dan sosial yang berimbang. GPM dikenal dengan amat banyaknya forum pertemuan yang berorientasikan kepentingan institusi, namun sangat terbatas dalam forum-forum studi yang dilakukan. Kedua, kecenderungan kemapanan dan hierarkis dari kelembagaan GPM sudah waktunya dipikirkan. Dalam arti, kelembagaan GPM harus memberi ruang yang cukup bagi kehidupan jemaat yang dialogis dan demokratis. Kepemimpinan gereja yang birokratis dan sentralistis tidak akan menolong jemaat berpikir secara lebih dinamis dan kreatif. Keakuan kelembagaan gereja akan menutup pintu bagi peran serta potensi intelektual awam dalam menggumuli persoalanpersoalan keagamaan dan kemasyarakatan secara bersama-sama. Sebagai gereja, GPM harus mampu mengambil jarak kritis terhadap kecenderungan ideologisasi dan birokratisasi yang terjadi di dalam masyarakat. Bila ini yang terjadi, Gereja akan kehilangan fungsi kritisnya di dalam masyarakat." 
Dalam perkembangan selanjutnya, beberapa agenda beragama kedepan yang dapat dipertimbangkan antar lain:

a. Membangun sebuah teologi agama-agama, baik sendiri-sendiri maupun bersama-sama oleh agama-agama, dan diharapkan menolong agamaagama tidak melihat perbedaan agama sebagai masalah, tetapi bagaimana perbedaan-perbedaan itu menolong agama-agama membangun sebuah tatanan masyarakat yang damai, adil, masyarakat bersaudara, yang saling menopang, mendukung, dan memperjuangkan common good (kebaikan bersama) bagi kemaslahatan bersama. Arah teologi semacam ini mengandung beberapa prinsip pokok, yakni: (a) hormat kepada kehidupan; (b) solidaritas dan keadilan; (c) toleransi dan kebenaran; (d) kesamaan hak dan kedudukan; dan (e) dialog dan kerjasama kemanusiaan sebagai panggilan (calling) bukan pilihan (an option).

b. Perlu membangun mekanisme pengorganisasian lembaga-lembaga keagamaan yang tidak saja well organized dengan struktur yang njlimet dan birokratik, melainkan sebuah mekanisme pengorganisasian yang memungkinkan kehidupan bersama tertata secara fungsional, sehingga peran dan fungsi agama itu berjalan lebih dinamis, kreatif, dan produktif.

c. Dalam konteks pengembangan pemuda lintas agama atau lintas iman, diperlukan sebuah forum antar-agama/iman yang dapat diposisikan sebagai sebuah forum bersama. Forum ini dapat dijadikan sebagai forum perjumpaan dan dialog pemuda lintas agama untuk membicarakan agenda-agenda bersama pemuda lintas agama, seperti:agenda mengkritisi ketidakadilan gender, kemiskinan, bahaya narkoba, HIV/AIDS, korupsi, kerusakan lingkungan, dan lainnya.

Saya optimis jika GPM bersama dengan stakeholders lainnya bisa terusmenerus menjaga dan merawat keragaman yang ada, maka masalah pluralisme tidaklah menjadi beban atau kuk yang berat, melainkan merupakan realitas sosial, sekaligus realitas teologis yang mesti diterima dan dihidupi dengan penuh syukur dan penuh sukacita. Dalam sukacita itu pula, saya ucapkan "Selamat ulang tahun yang ke-7o kepada Pak Brury!"

'Usulan agenda ini pernah saya utarakan pada tulisan saya lainnya, yakni 'Religiusitas Manusia Maluku dari Perspektif Protestan', dalam Berlayar Dalam Ombak Berkarya Bagi Negeri. Pemikiran Anak Negeri Untuk Maluku. 2012. Ambon: Ralahalu Institut, hlm. 421 . 


\section{Bacaan Rujukan}

Majelis Pekerja Harian Sinode GPM, 2016. Dokumen PIP-RIPP GPM.

Persekutuan Gereja-Gereja di Indonesia, 2015. Dokumen Keesaan Gereja Persekutuan Gereja-Gereja di Indonesia (DKG-PGI) 2014-2019. Jakarta: BPK Gunung Mulia \& PGI.

Ruhulessin, John, Chr. 2005. Etika Publik. Menggali dari Tradisi Pela di Maluku. Salatiga: Program Pascasarjana UKSW.

-, 2007. Pluralisme Berwajah Humanis. Sketsa Pemikiran.

Abidin Wakano \& Rudy Rahabeat (editor). Galang Press: Yogyakarta. , 2015. Gereja dan Kepemimpinan Publik. Sepuluh Tahun

Menanam dan Menyiram. Salatiga: UKSW Press. 2016. Mencari Cita Kemanusiaan Bersama. Pergulatan Keambonan dan Keindonesiaan. Salatiga: UKSW Press. Religiusitas Manusia Maluku dari Perspektif Protestan, dalam Berlayar Dalam Ombak Berkarya Bagi Negeri. Pemikiran Anak Negeri Untuk Maluku, 2012. Ambon: Ralahalu Institut.

, Jelajah Pemikiran Etika. Menuju Jalan Baru Etika Kristen di Indonesia, 2006. Elifas Maspaitella (editor), tt. tp. 